J. Clin. Chem. Clin. Biochem.

Vol. 26, 1988, pp. 685-688

(C) 1988 Walter de Gruyter \& Co.

Berlin - New York

\title{
Simplified Turbidimetric Determination of Apolipoproteins A-I, A-II and B Using a Microtitre Method
}

\author{
By M. Sandkamp, B. Tambyrajah \\ Institut für Klinische Chemie und Laboratoriumsmedizin (Zentrallaboratorium), \\ Westfälische Wilhelms-Universität Münster
}

\section{H. Schriewer}

Zentrallabor des Kreiskrankenhauses Lüdenscheid and

\section{G. Assmann}

Institut für Klinische Chemie und Laboratoriumsmedizin (Zentrallaboratorium), Westfälische Wilhelms-Universität Münster

(Received June 28, 1988)

Summary: A turbidimetric method is described for the determination of apolipoproteins A-I, A-II and B on microtitre plates.

Regression analysis of the resulting values showed a good correlation to apolipoprotein values determined turbidimetrically on Cobas Bio (apolipoprotein A-I, A-II), and those determined by means of radial immuno diffusion (RID) (apolipoprotein A-I: $\mathrm{r}=0.93, \mathrm{y}=1.02 \mathrm{x}-5.0, \mathrm{n}=63$; apolipoprotein A-II: $\mathrm{r}=0.90$, $\mathrm{y}=1.07 \mathrm{x}-5.6, \mathrm{n}=44$; apolipoprotein $\mathrm{B}: \mathrm{r}=0.92, \mathrm{y}=0.95 \mathrm{x}+9.0, \mathrm{n}=58$ ).

The variation coefficient in the series was $3.5 \%$ (apolipoprotein A-I, $\mathrm{n}=21$ ), 2.5\% (apolipoprotein A-II, $\mathrm{n}=20$ ) and $3.6 \%$ (apolipoprotein $\mathrm{B}, \mathrm{n}=19$ ); and the variation coefficient from day to day $3.1 \%$ (apolipoprotein $\mathrm{A}-\mathrm{I}, \mathrm{n} \equiv 45$ ), $4.2 \%$ (apolipoprotein $\mathrm{A}-\mathrm{II}, \mathrm{n}=39$ ) and $5.3 \%$ (apolipoprotein $\mathrm{B}(\mathrm{n}=48)$.

\section{Introduction}

Based on epidemiological $(1-4)$ and clincial $(5,6)$ studies it is known that a low HDL cholesterol value constitutes a risk factor for coronary heart disease, whereas a high LDL cholesterol value indicates an increased risk of protracting such a disease $(7, \overline{8})$.

Various clinical studies show that the quantification of apolipoproteins improves the predictability of coronary risk (9). There are several methods for determining apolipoproteins: radial immuno diffusion, rocket electrophoresis, radioimmunoassays, enzyme immunoassays, nephelometry, turbidimetry (10). Most of these methods are labour intensive, require special equipment and are hence unsuitable for processing the number of samples required for epidemiological studies.

This present article describes a turbidimetric method for quantification of apolipoproteins on microtitre plates.

\section{Material \\ Samples}

For this study we used serum from normo- and hypertriglyceridaemic patients, which had been collected for the PROCAMStudy (11). 


\section{Anti-serum}

Anti-serum used for apolipoprotein quantification was obtained from Boehringer, Mannheim (anti-h-apolipoprotein-AI-antiserum, order no. 726 478, anti-h-apolipoprotein-AII-antiserum, order no. 726486 , anti-h-apolipoprotein-B-antiserum, order no. 726 494).

\section{Standards}

Apolipoprotein A-I and A-II were measured with the Cobas Bio (Roche) and standardized with the immunoneph reference standard apoproteins human (Immuno, Heidelberg, order no. 4380105 ). Apolipoprotein B measurements, using radial immuno diffusion, were standardized with the immuno reference standard (Immuno, order no. 4910005 ). The apolipoprotein calibration serum (Boehringer, Mannheim, order no. 837 237) or immuno reference standard by Immuno, Heidelberg, are suitable standards for turbidimetric measurements on microtitre plates.

\section{Dilution}

For the dilution of antisera for turbidimetric measurements with the microtitre system, we used the anit-h-apolipoprotein antiserum diluent from Boehringer, Mannheim, order no. 779156.

\section{Microtitre plates}

The tests were carried out on flat-bottomed micro-well-dishes 96 (NUNC, Wiesbaden, order no. 269620 ). After careful cleaning these dishes can be used several times.

\section{Methods}

The apolipoprotein A-I and A-II quantification was performed on the Cobas Bio as previously described $(12,13)$.

Apolipoprotein B determination with radial immuno diffusion was carried out with the Mancini method (14). Anti-apolipoprotein B-antibody $(10 \mu \mathrm{l})$ was mixed with $20 \mathrm{ml}$ agarose solution $(10 \mathrm{~g} / \mathrm{l})$ in tris-barbital-lactate-buffer $(0.045 \mathrm{mmol} / \mathrm{l}$ tris, $0.015 \mathrm{mmol} / 1$ barbituric acid, $1.9 \mathrm{mmol} / 1 \mathrm{Na}$-azide, 0.21 $\mathrm{mmol} / \mathrm{l} \mathrm{Ca-lactate})$. The sample was $5 \mu \mathrm{l}$ of diluted serum $(1: 3$ in $0.15 \mathrm{~mol} / 1 \mathrm{NaCl}$ ). The standard was diluted $1: 1,1: 1,5,1: 2$, $1: 3,1: 4$ and $1: 6$ in $0.15 \mathrm{~mol} / 1 \mathrm{NaCl}$. Following an incubation period of 72 hours the ring diameters were evaluated after staining with Coomassie blue R (Serva, Heidelberg).

\section{Turbidimetric tests on microtitre plates}

Quantification of apolipoprotein A-I and A-II: The serum was pre-diluted $1: 60$ in $0.15 \mathrm{~mol} / 1 \mathrm{NaCl}$, the standard $1: 10-1: 320$ in geometric sequence. The antiserum was diluted $1: 11$ in antiserum diluent and incubated for 20 minutes at room temperature. For the determination of apolipoprotein A-I, $200 \mu \mathrm{l}$ of the diluted antibody, and $20 \mu$ diluted serum or diluted standard were pipetted in duplicate onto microtitre plates and incubated at room temperature for 90 minutes. For apolipoprotein A-II, the procedure was similar, but using $30 \mu$ l diluted serum. After careful shaking of the dish, turbidity was measured at $340 \mathrm{~nm}$ against a basic value $(200 \mu \mathrm{l}$ antibody dilution +20 $\mu \mathrm{l}$ or $30 \mu \mathrm{l}$ of $0.15 \mathrm{~mol} / \mathrm{l} \mathrm{NaCl}$ ):

\section{Quantification of apolipoprotein B}

The serum was prediluted $1: 30$ in $0.15 \mathrm{~mol} / 1 \mathrm{NaCl}$, the standard $1: 10-1: 160$ in geometric sequence. The antiserum was diluted $1: 11$ in antibody diluent and incubated for 20 minutes at room temperature. $200 \mu \mathrm{l}$ of antibody dilution, $30 \mu \mathrm{l}$ of serum and standard dilution were pipetted in duplicate on microtitre plates and incubated for 120 minutes at room temperature. Evaluation as for apolipoprotein A-I and A-II.

\section{Results and Discussion}

Comparison of the turbidimetric microtitre method (y) and turbidimetric method on the Cobas Bio (x) for apolipoprotein A-I and A-II

Regression analysis of paired values resulted in a good correlation of both methods: apolipoprotein A-I $\mathrm{r}=0.93, \mathrm{y}=1.02 \mathrm{x}-5.0, \mathrm{n}=63$ (fig. 1); apolipoprotein A-II $r=0.90, y=1.07 x-5.6, n=44$ (fig. 2 ).

Comparison of the turbidimetric microtitre method and radial immuno diffusion for apolipoprotein $B$

Regression analysis of turbidimetric values (y) and radial immuno diffusion values $(x)$ resulted in a good correlation of the paired values $(r=0.92, y=0.95 x$ $+9.8, \mathrm{n}=58)$ (fig. 3).

\section{Precision of the microtitre method}

The variation coefficient for the precision in the series was $3.5 \%(\overline{\mathrm{x}} \pm \mathrm{SD}: 1.22 \pm 0.043 \mathrm{~g} / \mathrm{l}, \mathrm{n}=21)$ for apolipoprotein A-I, $2.5 \%(\overline{\mathrm{x}} \pm \mathrm{SD}: 0.319 \pm 0.03 \mathrm{~g} / \mathrm{l}$, $\mathrm{n}=20)$ for apolipoprotein A-II, 3.6\% ( $\overline{\mathrm{x}} \pm$ SD: 1.01 $\pm 0.036 \mathrm{~g} / \mathrm{l}, \mathrm{n}=19$ ) for apolipoprotein $\mathrm{B}$. The vari-

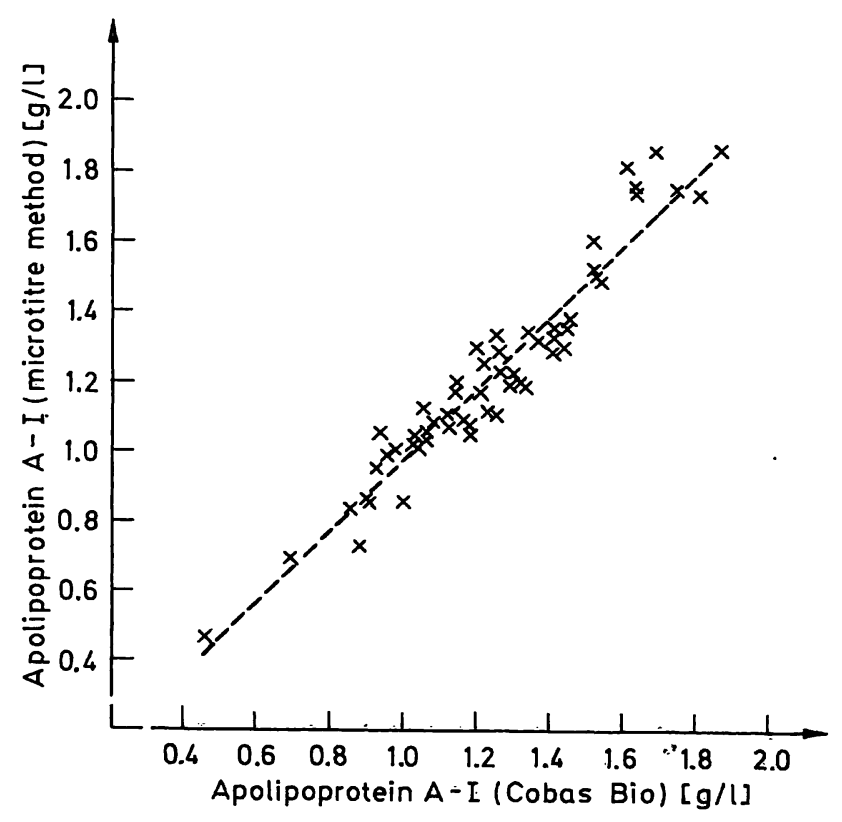

Fig. 1. Regression analysis of apolipoprotein A-I values analysed by turbidimetry on Cobas Bio vs. microtitre method $r=0.93, y=1.02 x-5.0, n \doteq 63$ 


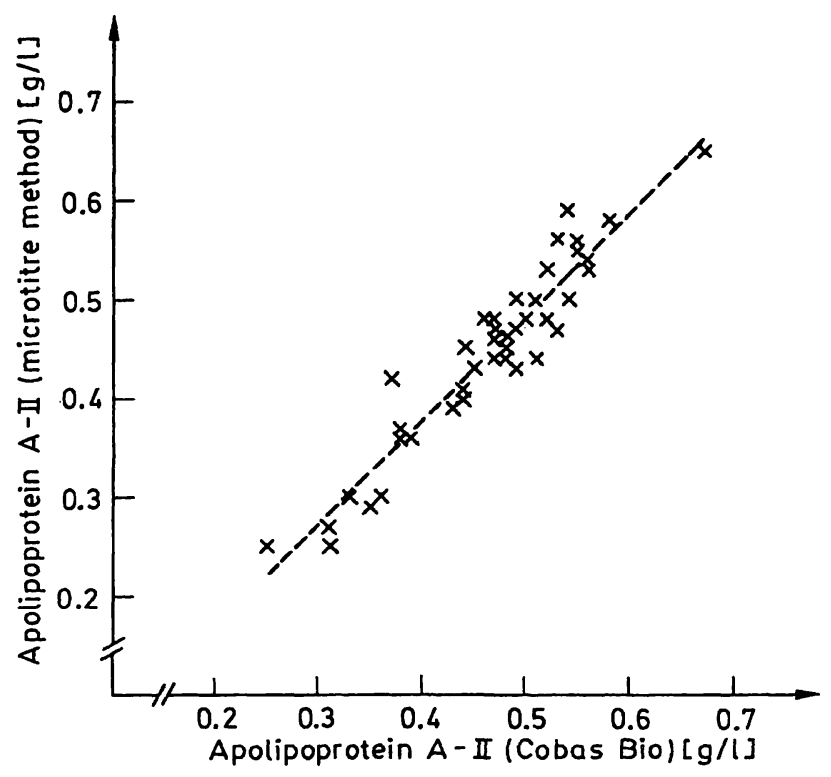

Fig. 2. Regression analysis of apolipoprotein A-II values analysed by turbidimetry on Cobas Bio vs. microtitre method

$r=0.90, y=1.07 x-5.6, n=44$

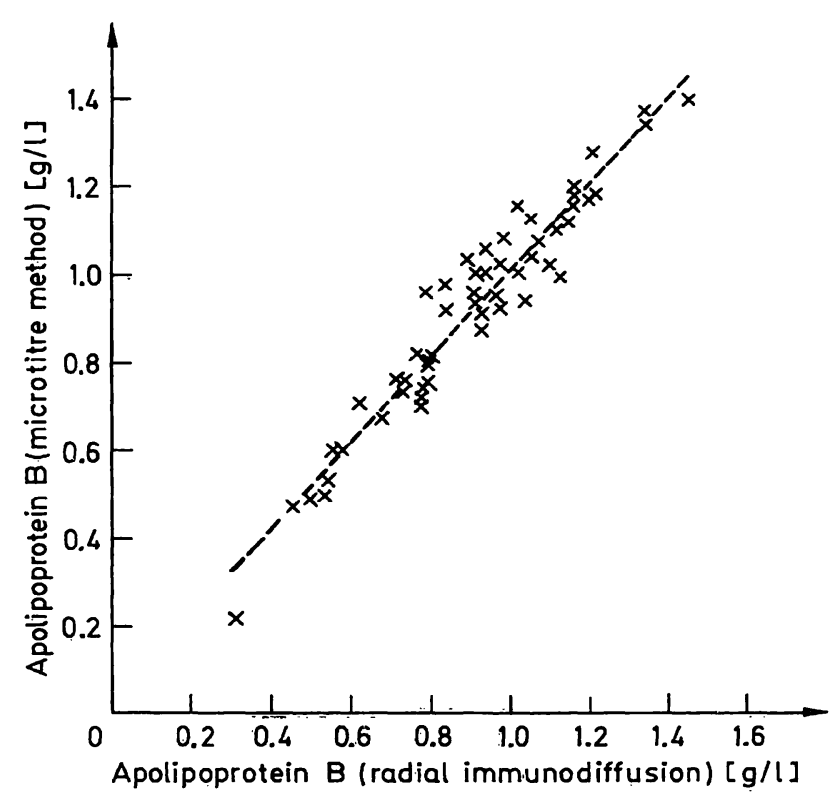

Fig. 3. Regression analysis of apolipoprotein B values analysed by radial immuno diffusion vs turbidimetry on microtitre plates

$\mathrm{r}=0.92, \mathrm{y}=0.95 \mathrm{x}+9.8, \mathrm{n}=58$

\section{References}

1. Miller, G. J. \& Miller, N. E. (1975) Lancet I, 16-19.

2. Berg, K., Borresen, A. L. \& Dahlen, G. (1976) Lancet $I$, $499-501$.

3. Gordon, T., Castelli, W. P., Hjortland, M. C., Kannel, W. B. \& Dawber, T. A. (1977) Am. J. Med. 62, 707-714.

4. Yaari, S., Goldbourt, U., Even-Zohar, S. \& Neufeld, H. N. (1981) Lancet $I, 1011-1015$. ation coefficient for day-to-day precision was 3.1\% $(\overline{\mathrm{x}} \pm \mathrm{SD}: 1.32 \pm 0.048 \mathrm{~g} / \mathrm{l}, \mathrm{n}=45)$ for apolipoprotein A-I, $4.2 \%(\bar{x} \pm$ SD: $0.32 \pm 0.013 \mathrm{~g} / \mathrm{l}, \mathrm{n}=39)$ for apolipoprotein A-II and 5.3\% ( $\bar{x} \pm$ SD: $0.76 \pm 0.04$ $\mathrm{g} / \mathrm{l}, \mathrm{n}=48$ ) for apolipoprotein $\mathrm{B}$.

\section{Linearity of the microtitre method}

In order to test for linearity, standard material in 0.15 $\mathrm{mol} / 1 \mathrm{NaCl}$ was increasingly diluted and measured. We found linearity in the region $0.1-4.5 \mathrm{~g} / 1$ for apolipoprotein A-I, $0.05-2.00 \mathrm{~g} / \mathrm{l}$ for apolipoprotein A-II and $0.1-3.00 \mathrm{~g} / 1$ for apolipoprotein B. Working ranges for this method are $0.23-3.70 \mathrm{~g} / 1$ for apolipoprotein A-I, $0.07-1.05 \mathrm{~g} / \mathrm{l}$ for apolipoprotein A-II and $0.14-2.24 \mathrm{~g} / 1$ for apolipoprotein $\mathrm{B}$.

Influence of hypertriglyceridaemia and bilirubin concentration

It was shown that triacylglycerol concentrations up to $8 \mathrm{~g} / \mathrm{l}$ and bilirubin up to $85 \mu \mathrm{mol} / 1 \mathrm{had}$ no influence on the precision of the results.

The method introduced here for the quantification of apolipoproteins offers several advantages over previously used methods: It uses far less reagents than the Cobas Bio and allows a faster throughput of samples. Two $\mathrm{ml}$ of antiserum on one microtitre dish are sufficient to process 42 samples together with standards within 2 hours. The apolipoprotein B determination in particular is considerably faster with this method than with traditional methods, such as radial immuno diffusion, rocket electrophoresis or enzyme immunoassays. The precision and accuracy of this method correspond to the standards of other methods which was demonstrated by the participation in a control trial of the CDC for apolipoprotein A-I and B.

A simplification of the method can be achieved by using an automated pipetting device. As ELISA test methods are increasingly used, most modern laboratories are equipped with a photometer for microtitre plates, so that the turbidimetric quantification of apolipoproteins on microtitre plates constitutes a cost and time saving alternative to methods used so far.
5. Barboriak, J. J., Anderson, A. J., Rimm, A. A. \& King, J. F. (1979) Metabolism 28, 735-738.

6. Kladetzky, R. G., Assmann, G., Walgenbach, S., Tauchert, P. \& Helb, H.-D. (1980) Artery 7, 191-205.

7. Gofman, J. W., Lindgren, F., Elliot, A., Mantz, W., Hewitt, J., Strisower, B., Herring, B., Herring, V. \& Lyon, T. P. (1950) Science $111,166-171$. 
8. Scanu, A. M. (1978) Ann. Clin. Lab. Sci. 8, 79-83.

9. Maciejko, J. J., Holmes, D. R., Kottke, B. A., Zinsmeister, A. B., Dinh, D. M. \& Mao, S. J. T. (1983) N. Engl. J. Med. $309,385-389$.

10. Rosseneu, M. (1987) In: European Lipoprotein Club. The First Ten Years, pp. 115-120.

11. Assmann, G. \& Schulte, H. (1986) PROCAM Trial (Monography) Panscientia Verlag, Zürich.
12. Schriewer, H., Emke, F., Funke, H., Schulte, H. \& Assmann, G. (1986) J. Clin. Chem. Clin. Biochem. 24, 627635.

13. Schriewer, H., Emke, F. \& Assmann, G. (1985) J. Clin. Chem. Clin. Biochem. 23, 355-359.

14. Mancini, G., Carbonara, A. O. \& Heremans, J. F. (1965) Int. J. Immunochem. 2, 235-254.

Prof. Dr. H. Schriewer

Kreiskrankenhaus Lüdenscheid

Zentrallabor

Paulmannshöher Straße 14

D-5880 Lüdenscheid 